\title{
IMPACT OF THE DIGITAL ECONOMY ON THE BANKING SECTOR
}

\author{
Oleg Litvishko ${ }^{1 *}$, Kamar Beketova ${ }^{2}$, Bibigul Akimova ${ }^{3}$, Assem Azhmukhamedova ${ }^{3}$, Gulnara \\ Islyam $^{4}$ \\ ${ }^{1}$ Plekhanov Russian University of Economics, 117997, Moscow, Russian Federation \\ ${ }^{2}$ Korkyt Ata Kyzylorda State University, 29A Aiteke bie str, 120014 Kyzylorda, Kazakhstan \\ ${ }^{3}$ L.N. Gumilyov Eurasian National University, Nur-sultan, Kazakhstan \\ ${ }^{4}$ Serikbayev East-Kazakhstan State Technical University, 070004, Ust-Kamenogorsk, \\ Kazakhstan
}

\begin{abstract}
In the article innovations in banking and foreign experience of digitalization studies. Catalyst of banking activity main factors of development of banking innovations considered as. The study allows us to set the boundaries of the digital banking model, determine the specific features of its activities and banking services to deepen the understanding of the subjects of the banking system of modern features of the development of the banking industry allows. Presented materials identification of the level of development of banking services for orientation and theoretical basis, it may be the digitalization of banking processes in terms of the impact of their activities on the transformation credit organizations and banking systems of countries around the world aimed at improving efficiency promotes coordination.
\end{abstract}

\section{Introduction}

The financial sector is an important element of the economy, which determines the speed and quality of changes. Currently, e-payments and e-Commerce are an integral part of the financial sector. The financial sector is a leader in the introduction and use of innovative technologies and digital services for interaction with clients.

In Kazakhstan, the use of digital public services has improved. the share of confirmed services over the past two years is the highest in the world. This is what BCG said in its new research.

There is every reason to believe that the development of innovative technologies contributes to the transformation of the financial sector to its current state and will influence its modernization in the future. Information technology has gone from massive computers to ultra-thin and portable laptops and tablets. With the advent of new technologies, business models are also changing, and new participants are emerging- FINTECH companies that challenge existing banks and offer innovative solutions that allow you to optimize many financial services: make them easier, more accessible and cheaper. Digital transformation will help financial companies attract customers, retain and generate revenue. Due to globalization and fierce competition, major banks from all over the world have started

\footnotetext{
*Corresponding author: ol-1@mail.ru
} 
to switch to a new business model-the digital banking model, which allows customers to perform operations via remote channels. Thus, many banks in Kazakhstan follow new trends in digital banking in order to maintain their competitiveness in the financial market. Studying the process of digitalization and their active implementation in the banking sector of Kazakhstan, we can say that today this process is in an active stage of development. Each Bank uses digital technology to expand its product ranges, which are focused on the specific needs of the buyer.

\section{Literature review}

Each state tries to improve the quality of life of the population. One of the ways to improve the quality of life of the people is the use of digital technology. On December 12, 2017, the Government of the Republic of Kazakhstan approved the "Digital Kazakhstan" program, which indicates the interest of state authorities and organizations in the issues of Informatization [1].

Prime Minister of Kazakhstan Askar Mamin took part in the plenary session of the conference "Digital Samruk" on the topic of digitalization of the economy of Kazakhstan.

The head of government noted the growing relevance of digitalization of the economy of Kazakhstan on the world stage to ensure its sustainable growth and competitiveness of the country. The main tool for achieving this goal is the state program "Digital Kazakhstan".

"The overall economic effect of the program in 2018 and 2019 exceeded 600 billion tenge. Significant progress has been made in the introduction of digital technologies in the provision of public services, education, health, Finance, transport and mining and metallurgical sectors, which has improved the position of Kazakhstan in the key world rankings, " A. Mamin said.

The head of the International monetary Fund, Christine Lagarde, said in a statement in Singapore that the digital currency is "safe", "cheap", and "potentially partially anonymous" for money transfers. Given these advantages, he urged the world's Central banks to consider issuing their digital money.

If you pay attention to another statement by Kristin Lagar, then with the help of digital money, transactions can be performed safely, easily and cheaply. "The more people use it, the cheaper and more useful this service will become. And private firms may not pay enough attention to security, " MS Lagarde said.

In turn, Daniyar Akishev spoke about the current issues of digitalization of the financial sector.

"The financial sector is one of the main industries where digital technologies are actively used. Financial services themselves are closely linked to the possibility of using IT infrastructure and digital solutions, " said Daniyar Akishev, former Chairman of the National Bank of Kazakhstan.

D. Akishev noted that in recent years, the provision of online services via the Internet and mobile applications has become the most important trend in the financial sector. To date, almost all banks in Kazakhstan have implemented a system of remote banking services.

"Today, Kazakhstan is actively developing remote customer service services - Internet banking, mobile banking applications, with which you can make remote payments, pay for services and other popular products of banks. More than 9 million users are registered in these systems, of which more than $30 \%$ regularly perform operations. The volume of transactions carried out through the Internet and mobile banking systems already exceeds the volume of non-cash payments made through POS terminals. $70 \%$ of financial transactions of business entities will also be carried out through electronic banking services, " said the representative of the National Bank E. Ashykbekov. 
The introduction of information technologies also affects the movement of the workforce and the personnel management system in the banking sector. The use of digital technologies allows you to reduce costs at all stages of human resource management through the process of automation, such technologies are used in the search and hiring of personnel, their training and management. At the same time, there is a growing demand for highly qualified personnel with experience in the financial sector and the necessary set of skills in the field of information and digital technologies. Modern banking technologies as a tool for supporting and developing banking business are based on a number of fundamental principles. New electronic technologies help banks change their relationships with customers and find new ways to make a profit. The authors highlight the main pros and cons of the digital economy. Do not underestimate the problems that many banks face when switching to innovative financial technologies. In General, becoming an economy on the path of Informatization is a fundamental factor in increasing efficiency, increasing income, and updating personnel in the labor market. [2]

\section{Methodology}

Currently, Kazakhstan is developing favorable conditions for digital digitalization of the financial industry, in particular, in the banking sector. Today, more than 7 million people receive services using remote banking systems. [3] Services are increasingly used regardless of time and place. Expanding the hours of virtual services also affects more traditional services, as consumers expect round-the-clock service or. The main difference between digital and traditional services is the cost structure. Digital services are heavily biased towards development and implementation costs, as ICT systems need to be installed and configured.

However, operating costs are very low. Traditional services have a higher cost of labor, and, in particular, working after hours is expensive [4]. Banks are gradually opening access to customers for online service in the 24/7/365 format. Increasing the pace of life in society as a whole has led to the need to provide services at any time and on any day of the week. This round-the-clock availability also puts pressure on banking. Since consumers use the Internet and mobile services around the clock, they also require appropriate payments. In addition, since mobile phone penetration in many countries is close to $100 \%$, services are used regardless of time and place. New-generation smartphones have contributed to the widespread use of mobile and Internet services. Thus, consumers can create Bank accounts, payment cards and deposits online without coming to the Bank's office. Many banks also use biometric technologies in their operations, such as voice recognition or face scanning based on a photo. For example, China has its own technology leaders like Alibaba and Tencent, which are improving non-cash payments and e-Commerce. But in Kazakhstan, innovations at the global level are also being born. Thanks to the information provided Forbes.kz, the 10 largest commercial banks in Kazakhstan have a stable position. These are JSC "Halyk Bank", JSC "Caspian Bank", JSC "Housing and construction savings Bank of Kazakhstan", JSC "Tsesnabank", JSC "DB Sberbank of Russia" (hereinafter-Sberbank), JSC "Bank CenterCredit", JSC "Fortebank", JSC "DB "Home Credit Bank", JSC "Altyn Bank" and JSC "ATF" [5]. Most of these banks have their own online version of banking services. For example, the largest Bank in Kazakhstan, Halyk Bank, after merging with Kazkommertbank, which owns $40 \%$ of the market, integrated myHalyk with Homebank, the previous owner of which was Kazkommertbank. MyHalyk can display custom credits, payment cards, and provides money transfers between accounts and others, payment services, account statements, and currency exchange between tenge and major currencies. Nevertheless, Kaspi Bank, ForteBank and Sberbank provide one of the most attractive online banking services to the public. To ensure security and fast payments, Sberbank and ForteBank launched the 
ApplePay online purchase (Sberbank; ForteBank). At the same time, Kaspi Bank offers customers installment purchases of a large number of products without any additional costs and commissions among the Bank's partner stores (Kaspi Bank). The growth of non-personal payments is $120 \%$, which is almost 5 times more than in Russia (25\%). Kaspi has also developed a unique terminal for accepting non-cash payments, which is called Kaspi POS. Every year, the number of consumers who use payment cards is growing. Payments using payment cards in stores are convenient, efficient and fast from the buyer's point of view, and are also secure using a PIN code. The number of cardholders increased to $20 \%$, i.e. by 5.2 million units. By 2019, the volume of non-cash payments amounted to 3.7 trillion tenge according to statistics of the national Bank of Kazakhstan.

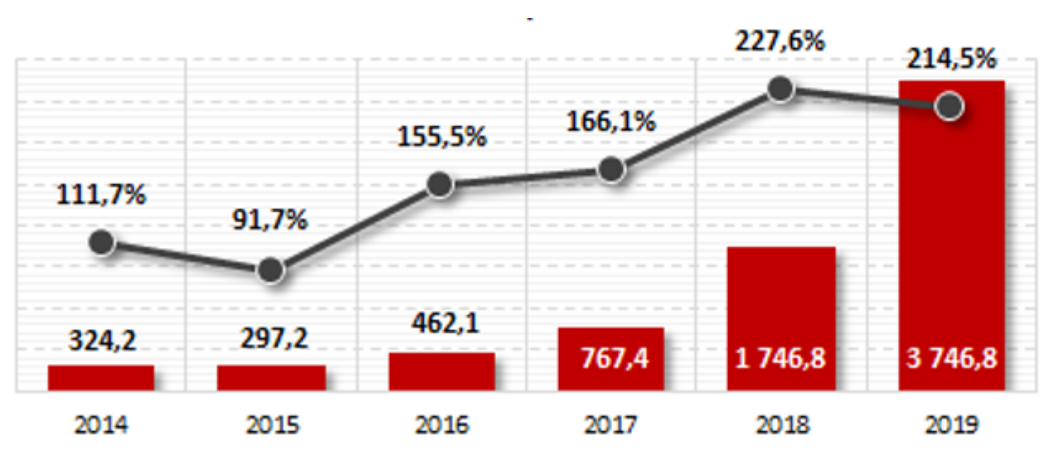

Fig.1. Non-cash payments in Kazakhstan, billion tenge [6].

The volume of non-cash payments on cards used in the Republic of Kazakhstan increased 2.1 times over the year. Thus, Almaty, without conceding to anyone, remains the leader in the number of non-cash transactions on payment cards. The share of non-cash payments in Almaty is $68 \%$, which is 2.6 trillion tenge. Nur-Sultana is in second place with a share of $8.6 \%$ of the Republic of Kazakhstan. The top three includes the Almaty region with a $5 \%$ share.

Table 1. Non-cash payments in Kazakhstan, January-may (billion tenge) [6].

\begin{tabular}{|l|r|r|r|r|r|r|}
\hline \multirow{2}{*}{} & \multicolumn{2}{|c|}{ Total } & \multicolumn{2}{c|}{$\begin{array}{c}\text { The growth of } \\
\text { total }\end{array}$} & \multicolumn{2}{c|}{ The share of RK } \\
\cline { 2 - 7 } & $2019 / 05$ & $2018 / 05$ & $2018 / 05$ & $2019 / 05$ & $2018 / 05$ \\
\hline Kazakhstan & $\mathbf{3 7 4 6 , 8}$ & $\mathbf{1 7 4 6 , 8}$ & $\mathbf{2 1 4 , 5 \%}$ & $\mathbf{2 0 0 0 , 0}$ & $\mathbf{1 0 0 , 0 \%}$ & $\mathbf{1 0 0 , 0 \%}$ \\
\hline Almaty & 2570,1 & 1105,3 & 232,5 & 1464,8 & 68,6 & 63,3 \\
\hline Nur-Sultan & 321,6 & 160,7 & 200,1 & 160,9 & 8,6 & 9,2 \\
\hline Almaty & 186,9 & 40,5 & 461,9 & 146,4 & 5,0 & 2,3 \\
\hline Karaganda & 109,5 & 77,8 & 140,8 & 31,7 & 2,9 & 4,5 \\
\hline Atyrau & 77,1 & 40,5 & 190,3 & 36,6 & 2,1 & 2,3 \\
\hline Shymkent & 65,3 & 49,4 & 132,1 & 15,9 & 1,7 & 2,8 \\
\hline Aktobe & 59,1 & 36,0 & 164,1 & 23,1 & 1,6 & 2,1 \\
\hline East Kazakhstan & 57,3 & 33,4 & 171,4 & 23,9 & 1,5 & 1,9 \\
\hline Kostanay & 54,9 & 33,3 & 165,0 & 21,6 & 1,5 & 1,9 \\
\hline West Kazakhstan & 52,3 & 30,6 & 171,0 & 21,7 & 1,4 & 1,8 \\
\hline Mangistau & 51,7 & 36,0 & 143,6 & 15,7 & 1,4 & 2,1 \\
\hline Pavlodar & 44,3 & 28,9 & 153,2 & 15,4 & 1,2 & 1,7 \\
\hline Akmolinsk & 32,0 & 34,9 & 91,6 & $-3,0$ & 0,9 & 2,0 \\
\hline Zhambyl & 23,8 & 14,5 & 164,6 & 9,3 & 0,6 & 0,8 \\
\hline North Kazakhstan & 20,8 & 14,4 & 144,4 & 6,4 & 0,6 & 0,8 \\
\hline Kyzylorda & 20,1 & 10,5 & 190,5 & 9,5 & 0,5 & 0,6 \\
\hline
\end{tabular}


Unfortunately, none of the financial institutions in Kazakhstan has launched the Open API platform, which allows for interaction between applications for third-party companies. This release provides the ability to launch digital and mobile Bank on the territory of Kazakhstan.

The majority of non-cash payments in Kazakhstan were made using POS terminals ( $45.7 \%$ and $26.0 \%$ of the total volume of non-cash payments) and Internet banking $(53.7 \%$ and $72.6 \%$ ). Cash withdrawal operations were mainly carried out through ATMs. According to the statistics of the National Bank of the Republic of Kazakhstan, it can be noted that the volume of cash withdrawals on cards is a "fuel" for the growth of the volume and number of non-cash transactions.

Table 2. Use of payment cards on the territory of the Republic of Kazakhstan, 2019 [6].

\begin{tabular}{|l|c|c|c|c|}
\hline \multirow{2}{*}{\multicolumn{1}{|c|}{ Indicators }} & \multicolumn{4}{|c|}{ January-December } \\
\cline { 2 - 5 } & \multicolumn{2}{|c|}{ Non-cash transactions } & \multicolumn{2}{c|}{ Cash withdrawal operations } \\
\cline { 2 - 5 } & $\begin{array}{c}\text { Number } \\
\text { (thousand } \\
\text { TRANS.) }\end{array}$ & $\begin{array}{c}\text { Amount } \\
\text { (million tenge) }\end{array}$ & $\begin{array}{c}\text { Number } \\
\text { (thousand } \\
\text { TRANS.) }\end{array}$ & $\begin{array}{c}\text { Amount } \\
\text { (million tenge) }\end{array}$ \\
\hline Total, incl. & 1146726,0 & 13304974,4 & 348414,9 & 15916249,4 \\
\hline POS-terminal & 524199,0 & 3454469,5 & 22633,3 & 2144828,1 \\
\hline ATM & 6646,9 & 194826,1 & 325781,6 & 13771421,3 \\
\hline $\begin{array}{l}\text { Internet and mobile } \\
\text { phone }\end{array}$ & 615873,4 & 9655303,4 & 0,0 & 0,0 \\
\hline Bank kiosk & 6,7 & 375,3 & 0,0 & 0,0 \\
\hline
\end{tabular}

The era of the digital economy was established with the opening of digital banks, one of which was JSC "Kaspi Bank". This Bank has a significant advantage over other banking systems by building an integrated financial electronic system for providing services. Kazakhstan's leading IT industry experts consider the platform Kaspi.kz the best digital service in the country [7]. Banks in Kazakhstan have created many options for the basic value proposition of convenience, acceptability, and security. To increase the number of payment cards, the country's commercial banks offer their customers additional loyalty programs, such as: travel insurance, cash refunds, discounts in stores, a points accumulation system, a free period of use, and gifts for the achieved turnover. Also, Kazakh banks are upgrading payment cards and have started issuing payment cards with a contactless function, and customers can pay for goods and services without entering their PIN code [8].

"We try to create cool services for our customers. To do this, of course, we use the most modern technologies available on the market. [9] But, first of all, we create our services based on the needs of our customers and the best global experience. And this approach shows a brilliant result. For example, a mobile app Kaspi.kz being one of the most popular apps in Kazakhstan, today it takes the first place in the "Finance" category in AppleStore and PlayMarket [10]. Application Kaspi.kz about 2 million Kazakhstanis already use it, making payments without commissions, managing personal finances online and buying various goods on credit and by installments, without leaving home, " said Sergey Timokhin, Executive Director of Kaspi Bank JSC. It is the most successful financial ecosystem, so Kaspi Bank in 2019 received a profit of 156.7 billion tenge, and assets amounted to 2 trillion tenge. Kaspi is not just a Bank, but an entire ecosystem that includes online payments, an online store, an online Bank, online transfers, 200 branches and 4 thousand terminals [11].

Digital banking is an exciting investment opportunity and an inevitable step in business, as outdated banks can no longer adequately serve the needs of their customers in the digital age. [12]. Customer demands simply cannot be met by traditional banks unable to catch up with the digital revolution. In the absence of real estate overheads and huge maintenance 
costs for legacy it systems, digital banks expect to grow multibillion-dollar balances over a few years with a share of full-time employees compared to traditional banks. For example, Atom Bank in the UK intends to grow into a balance sheet business worth 5 billion pounds over five years, with only 340 full-time employees, while the old Metro Bank has a balance of 2200 people. However, it is clear that most digital Bank employees will be engineers and data specialists, although, as always, the role of marketing should not be underestimated [13].

Many studies have shown that SWOT analysis can affect the company's performance. As with any other organization, SWOT analysis can also be applied to an online banking system so that you can analyze what its overall environment is and how effective it is in managing its core competencies. Table 1 shows the SWOT analysis matrix adapted to the internal and external environment of the online banking system [14].

Table 3. SWOT analysis of Internet banking.

\begin{tabular}{|c|c|}
\hline Strength & Weakness \\
\hline $\begin{array}{l}\text { Access at any time; } \\
\text { - Saves a lot of time; } \\
\text { - } \quad \text { Coster transaction with lower costs; } \\
\text { - Compenience for customers; } \\
\text { of scale; } \\
\text { Provides better convenience and } \\
\text { greater efficiency }\end{array}$ & $\begin{array}{l}\text { - Security issues in digital mode; } \\
\text { - } \quad \text { Sensitivity to the global economy; } \\
\text { The use of Internet banking depends } \\
\text { on the availability of the Internet; } \\
\text { - Can only target specific customers }\end{array}$ \\
\hline Opportunities & Threats \\
\hline $\begin{array}{l}\text { - Raising awareness of the benefits of } \\
\text { digital banking among people; } \\
\text { Integration of domestic banks with } \\
\text { foreign markets; } \\
\text { Better development in areas such as } \\
\text { risk management and CRM; } \\
\text { Developing a modern it base to avoid } \\
\text { system failures and provide an } \\
\text { efficient and secure platform for } \\
\text { online transactions. }\end{array}$ & $\begin{array}{l}\text { - } \quad \text { Any security-related issues or news } \\
\text { may pose a threat; } \\
\text { - } \quad \text { Tough competition; } \\
\text { - } \quad \text { Lack of effective rules; } \\
\text { - } \quad \text { Lack of customer loyalty }\end{array}$ \\
\hline
\end{tabular}

\section{Strength}

With the rapid development of the Internet and e-Commerce, the competitive advantage of Internet banking is becoming more noticeable, in particular, the effect of scale. More and more Internet users are ready to switch to online banking. Banks also violate geographical restrictions and can provide banking services on a global level to meet customer needs. [15]Through banking operations, such as expanding the number of employees to reduce unit costs, banks can achieve economies of scale. The advent of Internet banking can support more competitive advantages of economies of scale. First of all, in comparison with traditional Bank branches, the expansion of Internet banking will help to reduce Bank expenses. Second, if computer technologies are developed, Internet banking consolidates complex business and reduces transaction costs for both parties. Additional operations at the front Desk can also be placed in the background. Efficient data processing programs and fast online services not only increase the efficiency of banking operations, but also reduce costs and provide economies of scale [16].

Weakness

The decision of Internet banks to conduct most of their business online, in addition to presenting their strengths, generates potential weaknesses. In order to run their business and be effective, online banks must consolidate their operations in countries where there is an 
optimal level of it spending as a percentage of GDP, Internet availability, and people who own a personal computer. \% of the total population. Moreover, the target customer segment is very specific. Most of the clients who use online banking services are mostly people with a high level of education and a good understanding of it technologies. [17] for this reason, all those customers who do not fall into this category turn to traditional physical banks for their needs. In addition, most online banks rely heavily on Deposit products to generate their revenue, paying less attention to other financial offerings; this, as a result, prevents differentiation of their products, which is one of the main factors for achieving a competitive advantage. From the customer's point of view, the security of personal data and its integrity is one of the main problems. Online banks need to invest heavily in security software because account information theft and virus attacks on Bank databases occur with high frequency.

Opportunities

Cooperation between banks and other stakeholders provides the basis for implementing new business strategies that ultimately lead to value creation for both customers and banks. By offering a wider range of financial products for both risk-averse and risk-averse customers, starting with bonds, options, mutual funds and mortgages, online banks will be able to differentiate their services and thus gain a competitive advantage not only over other online banks, both domestic and foreign, but also traditional banks and other financial institutions. [18]

Threats

The main obstacle for online banks is a large number of competitors. Online banks are threatened by traditional banks that offer differentiated products, financial institutions that provide specific financial solutions, and, above all, foreign banks. the rapid development of the Internet actually requires that the laws governing online transactions are up-to-date, since in the case of financial losses to the detriment of customers or in other specific situations, there are no adequate compensatory measures. countermeasures. The world is currently going through difficult economic times. Trade wars, protectionist policies, and global downturns have affected the international banking system. [19]

It is natural to expect a well-designed digital Bank to become the cornerstone of a much larger financial ecosystem. Digital service providers such as insurers, brokers, asset managers, Robo-consultants, credit card issuers, cross-border payment providers, currency exchanges, P2P lenders, and so on can be considered important components of such an ecosystem. These companies will be significantly expanded to meet the financial needs of their clients by accessing the broader financial system through a digital Bank. At the same time, the Bank will benefit by receiving additional information about the needs and habits of its customers, thereby closing the information loop of feedback. For example, if a Bank's client house informs him or her that the roof needs repair, the Bank can immediately recommend several contractors, arrange offers, help the client choose the most suitable one, and arrange financing. Thus, in addition to the financial business, the digital Bank of the future can include various non-financial entities in its ecosystem. All these events will increase the Bank's social utility and public appreciation, while increasing its profitability. Banks should remember that there is no time to lose, because competition for their customers ' digital wallet from current digital leaders such as Google, Amazon, Facebook and Alibaba will be fierce.

The introduction of digital technologies in the banking platform has a significant impact on the workforce and the personnel management system, thereby reducing labor resources through the automation process. In this regard, there is a need to invent a new system for managing digital transformations in the Bank. We need to develop the following areas:

- To establish a connection with the audience;

- Staff recruitment and training;

- To store bulk information create a database; 
- Come up with and implement special mobile and computer applications;

- Improvement and development of business processes.

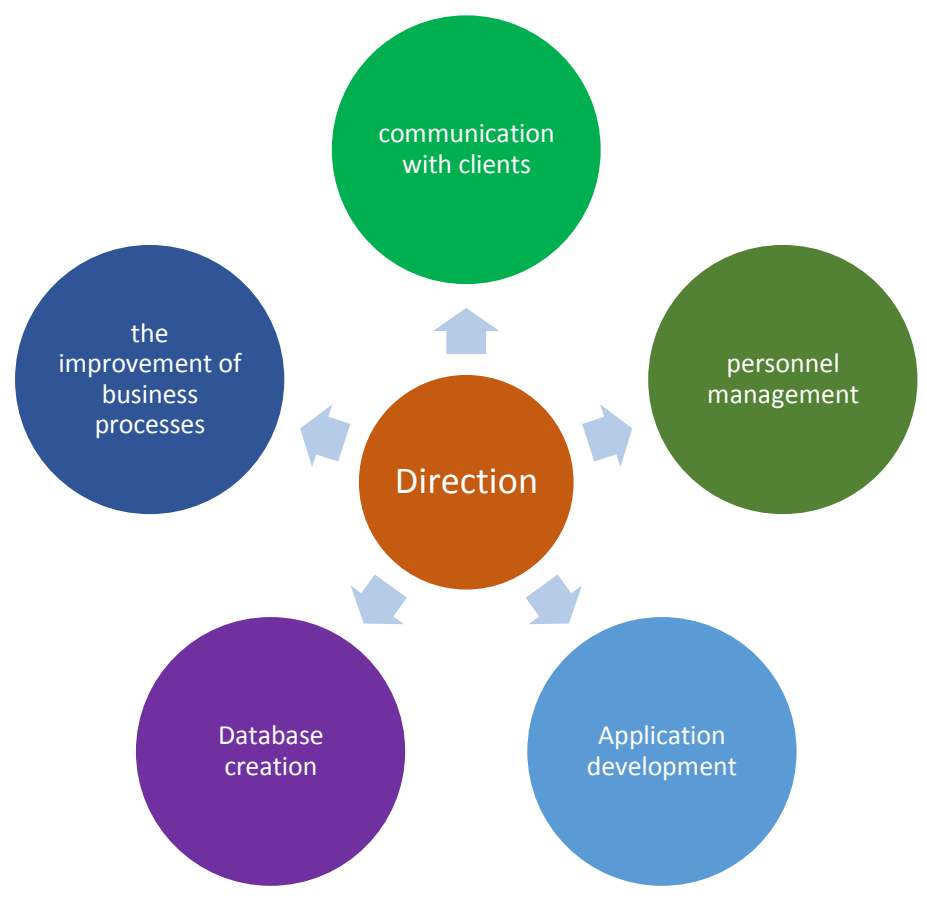

Fig. 2. System of main directions of application of digital technologies in the banking sector.

Kazakhstan's banking system is merging into the world, and the fight against Western competitors is unthinkable without relying on modern high-level information technologies. In the future, the main factors that allow us to remain competitive in the market will largely depend on the visions and strategies developed and implemented by banks. Payment cards play an important role in the modern market as a generally accepted payment tool. The most promising area of development of banking information technologies is Internet banking. It has a number of advantages:

$>$ it does not require installing additional software on your computer;

$>$ customers instantly get all the information about the status of their Bank accounts, which significantly saves time, eliminating the need for personal visits to the Bank and tracking transactions;

$>$ documents are exchanged electronically, but this does not remove the client's obligation to provide all necessary documents in the form of paper originals;

$>$ удобство convenience of operations saves time for Bank employees on paper work, and consequently leads to savings in Bank expenses [20].

In addition to the advantages of this system, you can also identify its disadvantages. First, the problem of non-financial risks is much higher in remote banking services than in traditional services. The sources of threats are software and human factors. It is possible to allocate attacks from the Internet malicious use of remote channels of service. The main reasons that constrain the growth of banking are: distrust of the majority of the adult population to Internet services. Phishing and pharming are modern Internet banking cybercrimes, two of the most organized crimes of the 21 st century, representing various ways 
that hackers try to manipulate users over the Internet. Depending on the sphere of influence or occurrence of Bank risk, they are divided into external and internal. External risks include risks that are not related to the Bank's or a particular client's activities, political, economic, and other risks. Internal risks, in turn, are divided into losses for the main and auxiliary activities of the Bank. The first ones represent the most common group of risks: credit, interest rate, currency and market risks. The second ones include losses on Deposit formation, risks for new types of activities, and risks of Bank abuse.

\section{Conclusion}

However, the rapid growth in the popularity of Internet banking confirms that there is a stable and effective demand for this new type of banking services. The cost of customer service via the Internet is minimal, which arouses the interest of customers. The development of the digital banking industry requires the efforts of every commercial Bank, as well as support from the State Bank. As the Manager of the national banking industry, the State Bank of Kazakhstan should strengthen the legal corridor and create a favorable environment plus supportive policies that facilitate the rapid application of digital technologies. Kazakhstan's commercial banks must also reorganize their management and strategy to meet the requirements of the new business model. Accordingly, banks must adjust their business culture while developing the appropriate human resources. In addition, commercial banks should also focus on managing communications, social media information, updating information technology platforms, developing network security management schemes, and classifying customers for better management in this digital age.

\section{References}

1. Sidorova, A. V. «Digital Kazakhstan»-process sozdaniya pravitel'stvennyj setevoj infrastruktury $\mathrm{v}$ Respublike Kazahstan. Vestnik kazahskogo-russkogo mezhdunarodnogo universiteta, 166 (2019).

2. Aptekman, A., Kalabin, V., Klincov, V., Kuznecova, E., Kulagin, V., \& YAsenovec, I.. Cifrovaya Rossiya: novaya real'nost'. Digital McKinsey, (07), 133 (2017).

3. Tayauova, G.. Advantages and disadvantages of outsourcing: analysis of outsourcing practices of Kazakhstan banks. Procedia-Social and Behavioral Sciences, 41, 188-195 (2012).

4. Tinnilä, M.. Impact of future trends on banking services. Journal of Internet Banking and Commerce, 17(2), 1 (2012).

5. Mingaleva, Z., Baurzhan, I., \& Assel, J.. Regional Aspects of Banks Activity: Comparative Analysis of International Operation of Russian and Kazakh Banks. International Journal of Economics and Financial Issues, 6(2S), 202-206 (2016).

6. https://nationalbank.kz/?docid=786\&switch=russian

7. Kovshova, T. P. K voprosu ob intellektual'nom kapitale banka. Innovacionnaya ekonomika: perspektivy razvitiya i sovershenstvovaniya, 4 (14) (2016).

8. Kodasheva, G. S., \& SHajhanova, G. S.. Razvitie didzhitalizacii bankovskogo obsluzhivaniya v Kazahstane. Molodezhnyj sbornik nauchnyh statej «Nauchnye stremleniya», (24) (2018).

9. Lygina, O., Makasheva, Z., \& Akhmetova, G. Ispol'zovanie korrelyacionnogo analiza dlya prognozirovaniya dohodnosti kommercheskih bankov Kazahstana (na primere AO «Kaspi bank»). European Journal of Management Issues, 25(2), 103-108 (2017). 
10. SHumkova, K. G., \& Tazhibaeva, A. L. Mekhanizmy povysheniya kachestva kreditnyh portfelej kommercheskih bankov Kazahstana. Finansovaya analitika: problemy i resheniya, (38) (2012).

11. Lipton, A., Shrier, D., \& Pentland, A.. Digital banking manifesto: the end of banks?. Massachusetts Institute of Technology (2016).

12. Sal'nikova, A. V.. Ispol'zovanie cifrovyh tekhnologij v bankovskom biznese (Doctoral dissertation, Belorussko-Rossijskij universitet) (2019).

13. Bachaev, U. A., \& Tat'yana, A. K. Development of the banking sector in the digital economy.

14. Drigă, I., \& Isac, C.. E-banking services-features, challenges and benefits. Annals of the University of Petro. ani. Economics, 14, 49-58 (2014).

15. Ziyadin S.T.,Tahtaeva R. SH. i dr. Ekonomicheskaya sushchnost' i klassifikaciya upravleniya bankovskimi riskami //Fundamental'nye issledovaniya. T. 2. №. 2. 2016.

16. ZHelezova, A. E. Cifrovaya ekonomikai: illyuziya ili reail'nyj proryv. Innovacionnaya nauka, (11) (2018).

17. Sayabek Ziyadin, Alau Zhanbolatova, Kairat Zhumanov and Almagul Jumabekova (2018). Relationship between bank competition and stability: the case of the UK. Banks and Bank Systems , 13(1), 98-114. doi:10.21511/bbs.13(1), (2018).

18. Ziyadin, S. Effect of the world global economic crisis on the condition of banking systems. Actual Problems of Economics, (134), 419-429 (2012).

19. Ziyadin, S., Litvishko, O., Dubrova, M., Smagulova, G., \& Suyunchaliyeva, M. Diversification tourism in the conditions of the digitalization. International Journal of Civil Engineering and Technology (2019).

20. Tovma, N., Baidildina, A., Ussabaev, A. Digital economy: Concept, characteristics and development prospects. Proceedings of the 32nd International Business Information Management Association Conference, IBIMA 2018 - Vision 2020: Sustainable Economic Development and Application of Innovation Management from Regional expansion to Global Growth - P. 6024-6031 (2018). 